\title{
HUBUNGAN KEBERSYUKURAN DENGAN TEACHER WELL-BEING PADA GURU YANG MENGAJAR DI SEKOLAH DASAR INKLUSI
}

\author{
Fitri Lestari Issom ${ }^{1}$, Zulfa Nadia ${ }^{2}$ \\ e-mail: fitrilestari@gmail.com ${ }^{1}$, zulfanadia47@gmail.com ${ }^{2}$ \\ Program Psikologi, Fakultas Pendidikan Psikologi, \\ Universitas Negeri Jakarta \\ Jakarta Timur
}

\begin{abstract}
Abstrak: Penelitian ini dilakukan untuk mengetahui hubungan kebersyukuran dengan teacher wellbeing pada guru yang mengajar di sekolah dasar inklusif. Metode penelitian yang digunakan adalah kuantitatif dengan teknik analisis deskriptif dan analisis korelasi. Sampel dalam penelitian ini adalah 185 orang guru sekolah dasar inklusif yang didapat dengan teknik purposive sampling. Variabel teacher well-being diukur menggunakan Teacher Well-Being Scale (TWBS) yang dikembangkan oleh Collie, Shapka, Perry \& Martin (2015) dengan nilai reliabilitas 0.85 dan nilai validitas berkisar antara 0.34 sampai 0.65. Variabel kebersyukuran diukur dengan menggunakan The Gratitude Questionnaire-Six Item Form (GQ-6) yang dikembangkan oleh McCullough, Emmons, \& Tsang (2002) dengan nilai reliabilitas 0.60 dan nilai validitas berkisar antara 0.34 sampai 0.48 . Hasil analisis korelasi Spearman-Rank menunjukkan bahwa terdapat hubungan signifikan ke arah positif antara kebersyukuran dengan teacher well-being pada guru yang mengajar di sekolah dasar inklusif $(\mathrm{r}=0.027$; dan $\mathrm{p}=0.163,(\mathrm{p}=0.05))$. Hubungan positif antara kebersyukuran dengan teacher well-being diartikan sebagai semakin tinggi kebersyukuran maka akan semakin tinggi pula teacher well-being pada guru yang mengajar di sekolah dasar inklusif.
\end{abstract}

Kata Kunci : teacher well-being, kebersyukuran, sekolah dasar inklusi

\section{THE RELATIONSHIP OF GRATITUDE WITH TEACHER WELL- BEING IN TEACHERS WHO TEACH IN INCLUSIVE ELEMENTARY $S C H O O L$}

\begin{abstract}
This research aims to find the relationship between gratitude and teacher well-being among teachers who teach in inclusive elementary schools. The research method used is quantitative with descriptive analysis techniques and correlation analysis. The sample in this study was 185 inclusive elementary school teachers who were purposely recruited. The teacher well-being variable was measured using the Teacher Well-Being Scale (TWBS) developed by Collie, Shapka, Perry \& Martin (2015) with a reliability value of 0,85 and validity value ranging from 0.34 to 0.65. The gratitude variable was measured using The Gratitude Questionnaire-Six Item Form (GQ-6) developed by McCullough, Emmons, \& Tsang (2002) with a reliability value of 0.60 and validity value ranging from 0.34 to 0.48. The results of the correlation analysis show that there is a significant relationship towards positive gratitude with teacher well-being for teachers who teach in inclusive elementary schools $(r=0.027$; and $p=0.163,(p=0.05))$. The positive relationship between gratitude and teacher well-being is defined as the higher the gratitude, the higher the teacher well-being of teachers who teach in inclusive elementary schools.
\end{abstract}

Keyword : teacher well-being, gratitude, inclusive elementary school 


\section{PENDAHULUAN}

Pendidikan merupakan salah satu kebutuhan dasar manusia serta kunci dalam memajukan suatu generasi penerus bangsa. Untuk mempersiapkan generasi penerus bangsa, pemerintah Indonesia memberikan layanan pendidikan pada seluruh lapisan masyarakat, termasuk anak berkebutuhan khusus (ABK). Pendidikan untuk ABK tidak hanya bisa didapatkan pada sekolah luar biasa (SLB) saja, namun juga bisa didapatkan pada sekolah reguler yang menyelenggarakan pendidikan inklusif. Pendidikan inklusif menurut Permendiknas Nomor 70 tahun 2009 didefinisikan sebagai suatu sistem penyelenggaraan pendidikan yang memberikan kesempatan kepada semua peserta didik yang memiliki kelainan dan memiliki potensi kecerdasan dan atau bakat istimewa untuk mengikuti pendidikan atau pembelajaran dalam satu lingkungan pendidikan secara bersama-sama dengan peserta didik pada umumnya. Sehingga dalam pendidikan inklusif peserta didik berkebutuhan khusus dapat belajar bersama dengan peserta didik lainnya di sekolah reguler (Wahyudi \& Kristiawati, 2016).

Melalui Pasal 4 ayat 1 Permendiknas Nomor 70 tahun 2009, dijelaskan bahwa pemerintah kabupaten atau kota menunjuk paling sedikit satu sekolah dasar, dan satu sekolah menengah pertama pada setiap kecamatan dan satu satuan pendidikan menengah untuk menyelenggarakan pendidikan inklusif yang wajib menerima peserta didik ABK. Melalui PP ini pemerintah memberikan hak sepenuhnya pada ABK untuk memilih sekolah mana yang akan dituju, baik itu sekolah reguler maupun sekolah khusus, dan sekolah tersebut wajib menyediakan akomodasi yang layak untuk ABK (Ahmad, 2020).

Dalam mewujudkan keberhasilan penyelenggaraan program sekolah inklusi, sekolah reguler harus menyiapkan segala komponen yang berkaitan dengan pendidikan inklusif. Salah satunya adalah guru sebagai tenaga pendidik (Wahyudi \& Kristiawati, 2016). Namun, pada kenyataannya masih banyak dari sekolah reguler yang belum siap. Dari segi guru misalnya, banyak guru yang memiliki latar pendidikan yang tidak sesuai, sehingga memiliki pengetahuan terbatas mengenai anak-anak berkebutuhan khusus dan sekolah inklusif. Kurangnya pemahaman guru tersebut kemudian menimbulkan dampak pada permasalahan yang muncul berikutnya, yakni guru kesulitan dalam kegiatan belajar mengajar di kelas yang ada ABK nya. Oleh sebab itu, diperlukan kerja sama antara guru dengan Guru Pembimbing
Khusus (GPK) dalam menangani siswa berkebutuhan khusus, sebab GPK mempunyai kualifikasi akademik terkait cara penanganan ABK. Hanya saja, jumlah GPK terbatas dan tidak setiap hari berada di kelas sehingga tidak selalu mendampingi guru. Akibatnya, guru harus mampu mempelajari sendiri karakteristik dari setiap siswa yang ada di kelasnya.

Guru memegang peranan penting dalam proses pembelajaran yang inklusif. Menurut Stark, Gordon-Burns, Purdue, Rarere-Briggs, \& Turnock (2011) menjadi guru sekolah inklusif tidak mudah. Sebab, beban mengajar anak berkebutuhan khusus dirasa lebih berat dibandingkan dengan anak normal. Perubahan sekolah reguler menjadi sekolah inklusif dapat membuat beban guru bertambah. Hal tersebut diyakini berdasarkan hasil penelitian Nadia Amira mengenai gambaran teacher well-being pada guru yang mengajar di sekolah dasar inklusi (Fatimatuzzahra, 2020) yang menemukan bahwa beban kerja guru semakin meningkat sejak mengajar di sekolah dasar inklusi.

Pengalaman-pengalaman yang dimiliki guru selama mengajar di sekolah dasar inklusif dapat membentuk well-being pada guru. Well-being didefinisikan oleh Ryan \& Deci sebagai "terbuka, terlibat dan berfungsi secara sehat" (Collie, Shapka, Perry \& Martin 2015). Secara lebih luas, well-being didefinisikan sebagai evaluasi positif seseorang terhadap kehidupannya, termasuk kepuasan hidup, rendahnya tingkat depresi dan kecemasan, serta emosi dan mood yang positif (Diener, Suh, \& Oishi, 1997). Seiring berjalannya waktu, konstruk well-being terus berkembang hingga memunculkan konstruk khusus bagi guru yakni teacher well-being.

Teacher well-being menurut Collie (2014) adalah well-being yang dirasakan oleh guru (seperti perasaan terbuka, terlibat dan berfungsi penuh) di tempat kerja (dalam hal ini sekolah) yang merupakan hasil dari pemaknaan terhadap pengalaman-pengalamannya. Well-being pada guru dapat dilihat dari stress dan burnout. Dapat juga dilihat dari faktor-faktor di mana lingkungan kerja guru mendukung well-being nya di sekolah. Faktor-faktor yang terkait dengan well-being pada guru yaitu workload well-being (kesejahteraan guru yang berhubungan dengan beban kerja); organizational well-being (kesejahteraan guru yang berhubungan dengan organisasi); dan student interaction well-being (kesejahteraan guru yang berhubungan dengan interaksi siwa). Ketiga aspek tersebut bila dimaknai secara positif oleh guru akan membantunya saat bekerja.

Konstruk well-being yang dikaitkan dengan 
guru dapat disebut sebagai teacher well-being. Terdapat beberapa faktor yang dapat memengaruhi wellbeing pada diri individu (Dewi \& Nasywa, 2019). Di antaranya adalah dukungan sosial, kebersyukuran, forgiveness, kepribadian, self-esteem, dan spiritualitas. Dampak teacher well-being menurut Turner \& Theilking (2019) yakni guru dengan tingkat teacher well-being yang baik akan berdampak pada cara guru mengajar dan pembelajaran siswa. Teacher well-being penting, karena guru yang berfungsi dan berkembang dengan baik akan menjadi guru yang terbaik (Winesa \& Saleh, 2020).

Menurut Hasemeyer (2013), salah satu hal positif yang paling berkontribusi pada well-being bagi individu adalah dengan cara bersyukur. Kebersyukuran dalam bahasa Inggris disebut gratitude. Kata gratitude berasal dari bahasa latin gratia yang memiliki arti kebaikan, kemuliaan atau rasa terima kasih (Pruyer dalam Emmons \& McCullough, 2003). Rasa syukur menurut Emmons dan McCullough (2003) adalah pengaruh moral yang memotivasi prososial perilaku, seseorang akan mengantisipasi konsekuensi atau tindakan yang berbeda pada kecenderungan syukur dan kebahagiaan. Bersyukur adalah suatu bentuk emosi positif yang mengekspresikan kebahagiaan dan berterima kasih karena adanya penghargaan, pemberian, kebaikan yang diterima seseorang. Mereka juga menyatakan bahwa individu yang bersyukur disebabkan karena adanya kesadaran diri dalam menerima kebaikan, penghargaan, pemberian dari Tuhan, orang lain, dan lingkungan sekitarnya sehingga mendorong untuk membalas, memberi penghargaan, serta berterima kasih atas apa yang diterimanya. Bentuk bersyukur dapat berupa perkataan, perbuatan, dan perasaan.

Terdapat empat aspek kebersyukuran menurut McCullough, Emmons \& Tsang (2002), yaitu intensity (mencakup perasaan intens akibat emosi positif dari rasa syukur yang dirasakan oleh individu); frequency (mencakup peristiwa-peristiwa dalam hidup yang membuat seseorang merasa bersyukur); Span (sejumlah kondisi kehidupan di mana seseorang merasa bersyukur setiap waktunya), dan density (seberapa banyak hal-hal yang disyukuri dan kepada siapa saja rasa syukur tersebut dilimpahkan).

Pada penelitian oleh Putri, Sukarti \& Rachmawati (2016) ditemukan bahwa pelatihan kebersyukuran terbukti berperan dalam upaya menurunkan stres kerja pada guru inklusi. Selanjutnya pada penelitian oleh Fatimatuzzara (2020) ditemukan bahwa terdapat rasa syukur atau kebersyukuran yang dirasakan oleh guru dari pengalaman-pengalamannya mengajar di sekolah dasar inklusi. Berdasarkan pemaparan di atas, peneliti memiliki asumsi bahwa kebersyukuran berperan pada tingkat teacher well-being guru yang mengajar di sekolah dasar inklusif. Penelitian ini bertujuan untuk melihat hubungan kebersyukuran dengan teacher well-being pada guru yang mengajar di sekolah dasar inklusif.

\section{METODE PENELITIAN}

Penelitian ini merupakan penelitian kuantitatif yang menggunakan metode non-probability dengan teknik purposive sampling. Subjek penelitian ini adalah 185 orang guru yang mengajar sekolah dasar inklusif di Jabodetabek dan pernah mengajar siswa berkebutuhan khusus di sekolah dasar inklusif.

Instrumen penelitian. Konstruk Teacher WellBeing diukur dengan Teacher Well-Being Scale (TWBS) yang dibuat oleh (Collie, Shapka, Perry \& Martin, 2015) berdasarkan tiga aspek teacher well-being yaitu workload well-being, organizasional well-being, dan student interaction well-being. TWBS merupakan instrumen penelitian berbentuk skala likert yang terdiri dari 16 item pernyataan dengan 7 opsi skala likert. Peneliti telah melakukan alih bahasa ke dalam bahasa Indonesia pada alat ukur ini dan telah dilakukan expert judgement oleh dosen ahli. Instrumen penelitian ini pun telah melalui uji reliabilitas dengan hasil koefisien alfa sebesar 0,85 yang dapat diartikan sebagai alat ukur yang memiliki reliabilitas yang baik. Serta hasil uji validitas berkisar antara 0,34 sampai 0,65 sehingga seluruh butir item memiliki nilai yang lebih besar dari $r$ tabel 0,3 dan tidak ada butir item yang dinyatakan gugur. Jadi, seluruh butir item pernyataan yang terdapat pada instrumen TWBS dapat dinyatakan layak sebagai instrumen untuk mengukur data penelitian teacher well-being. Skoring total pada alat ukur ini dilakukan dengan cara menjumlahkan setiap item, sehingga dapat mengetahui tingkat teacher well-being seorang guru. Semakin tinggi skor maka semakin tinggi pula tingkatan teacher well-being guru tersebut. Skor tingkat teacher well-being guru terbagi menjadi tiga kategori, yaitu kategori rendah, sedang dan tinggi. Kategori tersebut ditentukan berdasarkan perhitungan mean teoritik. Nilai rendah berada di bawah 48 dan nilai tinggi berada di atas 80 , sementara nilai sedang berada di antara 48 - 80 .

Konstruk kebersyukuran diukur dengan The Gratitude Questionnaire-Six Item Form (GQ-6) yang dikembangkan oleh McCullough, Emmons, dan Tsang (2002) berdasarkan empat aspek kebersyukuran yakni intensity, frequency, span dan density. GQ-6 merupakan instrumen penelitian berbentuk skala likert yang 
terdiri dari enam item kebersyukuran dengan dua jenis pernyataan item favorable dan item unfavorable dengan 7 opsi skala likert. Peneliti telah melakukan alih bahasa ke dalam bahasa Indonesia pada alat ukur ini dan telah dilakukan expert judgement oleh dosen ahli. Instrumen penelitian ini pun telah melalui uji reliabilitas dengan hasil koefisien alfa sebesar 0,60 yang dapat diartikan sebagai alat ukur yang memiliki reliabilitas yang cukup baik. Serta hasil uji validitas berkisar antara 0,34 sampai 0,48 artinya seluruh butir item memiliki nilai yang lebih besar dari r tabel 0,3. Sehingga, tidak ada butir item yang gugur dan seluruh butir item pernyataan yang terdapat pada instrumen GQ-6 dapat dinyatakan layak sebagai instrumen untuk mengukur data penelitian kebersyukuran. Scoring total pada alat ukur ini dilakukan dengan cara menjumlahkan setiap item. Semakin tinggi skor pada setiap item, maka semakin tingga pula tingkatan kebersyukuran pada responden tersebut. Skor tingkat kebersyukuran guru terbagi menjadi tiga kategori, yaitu kategori rendah, sedang dan tinggi. Kategori tersebut ditentukan berdasarkan perhitungan mean teoritik. Nilai rendah berada di bawah 18 dan nilai tinggi berada di atas 30, sementara nilai sedang berada di antara 18 - 30 .

Prosedur penelitian. Penelitian diawali dengan memilih instrumen yang tepat sesuai dengan teori, kemudian expert judgement dilakukan oleh dua dosen ahli. Setelah itu, peneliti melakukan uji keterbacaan kepada 10 orang. Hasil uji keterbacaan menunjukkan terdapat beberapa masukan pada beberapa butir soal. Setelah butir soal diperbaiki dan dianggap sesuai, instrumen diujikan kepada 50 partisipan. Hasil dari uji instrumen memperlihatkan bahwa kedua instrumen, Teacher well-Being Scale (TWBS) dan The Gratitude Questionnaire-Six Item Form (GQ6) merupakan instrumen yang valid dan reliabel. Penelitian dilakukan secara daring dalam bentuk kuesioner menggunakan formulir Google. Peneliti menyebarkan tautan kuesioner kepada para guru yang sedang mengajar di sekolah dasar inklusif daerah Jabodetabek.

Analisis data dilakukan dengan SPSS IBM 25 melalui metode analisis deskriptif untuk melihat data demografis dari subjek dan metode analisis korelasi Spearman-Rank untuk melihat hubungan dari kebersyukuran dan teacher well-being.

\section{HASIL DAN PEMBAHASAN}

\section{Hasil}

Pada penelitian ini diperoleh sebanyak 185 set data partisipan yang diolah oleh peneliti.
Table 1. Demografi Partisipan

\begin{tabular}{|c|c|c|}
\hline \multirow[t]{2}{*}{ Karakteristik } & \multicolumn{2}{|c|}{ Sampel Menyeluruh } \\
\hline & $\mathrm{n}$ & $\%$ \\
\hline \multicolumn{3}{|l|}{ Gender } \\
\hline Laki-laki & 39 & 21.1 \\
\hline Perempuan & 146 & 78.9 \\
\hline \multicolumn{3}{|l|}{ Lokasi Sekolah } \\
\hline \multicolumn{3}{|l|}{ Tempat Mengajar } \\
\hline Jakarta & 52 & 28.1 \\
\hline Bogor & 16 & 8.6 \\
\hline Depok & 20 & 10.8 \\
\hline Tangerang & 8 & 4.3 \\
\hline Bekasi & 89 & 48.1 \\
\hline \multicolumn{3}{|l|}{ Usia } \\
\hline $\begin{array}{l}\text { Dewsa Awal } \\
(18-40)\end{array}$ & 107 & 57.7 \\
\hline $\begin{array}{l}\text { Dewasa Madya } \\
(41-60)\end{array}$ & 78 & 42.3 \\
\hline $\begin{array}{l}\text { Dewasa Akhir } \\
(>60)\end{array}$ & 0 & 0 \\
\hline \multicolumn{3}{|l|}{ Lama Mengajar } \\
\hline$>1-6$ & 49 & 26.4 \\
\hline $7-12$ & 40 & 21.6 \\
\hline $13-18$ & 67 & 36.2 \\
\hline $19-24$ & 19 & 10.2 \\
\hline $25-30$ & 6 & 3.2 \\
\hline $31-36$ & 3 & 1.6 \\
\hline $37-42$ & 1 & 0.5 \\
\hline
\end{tabular}

\begin{tabular}{ccc}
\hline $\begin{array}{c}\text { Pendidikan } \\
\text { Terakhir }\end{array}$ & & \\
SMA & 6 & 3.2 \\
SMK & 2 & 1.1 \\
MA & 1 & 0.5 \\
D1 & 2 & 1.1 \\
D2 & 2 & 1.1 \\
D3 & 2 & 1.1 \\
S1 & 153 & 82.7 \\
S2 & 17 & 9.2 \\
\hline
\end{tabular}

\begin{tabular}{ccc}
$\begin{array}{c}\text { Jenjang Kelas } \\
\text { yang Diajar }\end{array}$ & & \\
Kelas 1 & 26 & 17.2 \\
Kelas 2 & 20 & 10.8 \\
Kelas 3 & 22 & 11.9 \\
Kelas 4 & 36 & 19.5 \\
Kelas 5 & 28 & 15.1 \\
Kelas 6 & 53 & 28.6 \\
\hline Total & 185 & 100
\end{tabular}

Tabel 1 di atas menunjukkan data karakteristik partisipan di mana partisipan didominasi oleh perempuan sebanyak 146 (78.9\%) sedangkan partisipan laki-laki sebanyak 39 orang (21.1\%). Lokasi sekolah tempat partisipan mengajar di Jakarta sebanyak 52 
(28.1\%), Bogor sebanyak 16 (8.6\%), Depok sebanyak $20(10.8 \%)$, Tangerang sebanyak 8 (4.3\%), dan Bekasi sebanyak 89 (48.1\%). Usia partisipan paling banyak ada pada kategori dewasa awal (18-40) kemudian dewasa madya (41-60), dan tidak ada partisipan pada kategori dewasa akhir (>60). Lama mengajar partisipan dimulai dari satu tahun kurang hingga 39 tahun, dengan jumlah partisipan paling banyak mengajar berada pada rentang 13-18 tahun. Pendidikan terakhir partisipan dimulai dari jenjang SMA sederajat hingga jenjang S2, dengan jumlah partisipan paling banyak mengajar berada pada jenjang S2. Jenjang kelas yang diajar partisipan dimulai dari kelas 1 hingga kelas 6, dengan jumlah partisipan paling banyak mengajar berada pada kelas 6 .

Table 2. Gambaran Umum Variabel Penelitian

\begin{tabular}{lccc}
\hline Variabel & Mean & Median & SD \\
\hline $\begin{array}{l}\text { Teacher Well- } \\
\text { Being }\end{array}$ & 95.45 & 96.00 & 7.687 \\
Kebersyukuran & 35.43 & 36.00 & 4.079 \\
\hline
\end{tabular}

**Korelasi signifikan pada level 0.05 (two-tailed).

Berdasarkan pembagian kategori skor teacher well-being rendah, sedang, dan tinggi, sebanyak 4 orang guru berada dikategori sedang $(2.2 \%)$ dan 181 orang guru berada dikategori tinggi (97.8\%). Kebersyukuran guru memiliki mean sebesar 35.43; median sebesar 36.00; dan SD sebesar 4.079. Berdasarkan pembagian kategori skor kebersyukuran rendah, sedang, dan tinggi, sebanyak 18 orang guru berada di kategori sedang $(9.7 \%)$ dan 167 orang guru berada di kategori tinggi $(90.3 \%)$.

Table 3. Gambaran Variabel Penelitian berdasarkan Gender dan Lama Mengajar

\begin{tabular}{|c|c|c|c|c|}
\hline \multirow[t]{2}{*}{$\overline{\text { Variabel }}$} & \multicolumn{2}{|c|}{$\begin{array}{l}\text { Teacher } \\
\text { Well-Being }\end{array}$} & \multicolumn{2}{|c|}{ Kebersyukuran } \\
\hline & Mean & Sig & Mean & Sig \\
\hline \multicolumn{5}{|l|}{$\overline{\text { Gender }}$} \\
\hline Laki-laki & 102.09 & 0.232 & 77.82 & 0.046 \\
\hline Perempuan & 90.57 & & 97.05 & \\
\hline \multicolumn{5}{|l|}{ Lama } \\
\hline \multicolumn{5}{|l|}{ Mengajar } \\
\hline$>1-6$ & 89.58 & 0.559 & 85.23 & 0.344 \\
\hline $7-12$ & 88.37 & & 98.13 & \\
\hline $13-18$ & 90.06 & & 91.93 & \\
\hline $19-24$ & 115.66 & & 113.97 & \\
\hline $25-30$ & 105.75 & & 81.50 & \\
\hline $31-36$ & 111.83 & & 86.83 & \\
\hline $37-42$ & 80.50 & & 16.00 & \\
\hline
\end{tabular}


well-being pada guru yang mengajar di sekolah dasar inklusi. Sebagaimana menurut (Dewi \& Nasywa, 2019) faktor-faktor tersebut yakni dukungan sosial, forgiveness, kepribadian, self-esteem, dan spiritualitas.

Berdasarkan data ditemukan bahwa 185 orang responden pada penelitian ini diketahui mayoritas responden memiliki tingkat teacher well-being yang tinggi (97.8\%) dan tingkat kebersyukuran yang tinggi (90.3\%). Hasil tersebut bertolak belakang dengan asumsi penelitian ini yang merujuk pada penelitian terdahulu bahwa terdapat perbedaan beban mengajar yang dialami oleh guru yang mengajar di sekolah dasar inklusi. Terdapat beberapa faktor yang dapat memengaruhi tingginya tingkat serta tingginya tingkat kebersyukuran. Berdasarkan hasil penelitian, diketahui bahwa usia responden rata-rata berada pada usia 23 tahun sampai 53 tahun yang artinya responden telah memasuki fase dewasa awal dan dewasa madya. Fase dewasa awal dan fase dewasa madya menunjukkan kematangan seseorang sebagai individu (Nofriza, 2020). Di mana fase dewasa awal menunjukkan setiap individu akan banyak belajar, melatih diri untuk semakin matang, sabar, rasional dan ikhlas dalam menghadapi masalah dan konflik yang dihadapi baik dengan dirinya sendiri maupun dengan orang lain. Kemudian pada fase dewasa madya pembelajaran tersebut sudah menjadi bagian dari kehidupannya. Kematangan, kesabaran, dan keikhlasan sudah dimiliki dan menjadi kepribadian yang tidak bisa dipisahkan dari kehidupannya (Nofriza, 2020). Jadi, berdasarkan hal tersebut, kedewasaan responden pada penelitian ini memungkinkannya untuk menerima pengalamannya sebagai guru di sekolah tempatnya mengajar.

Berdasarkan hasil penelitian diketahui banyak responden yang telah mengajar lebih dari 7 tahun (73,3\%). Hal tersebut menunjukkan responden sudah memiliki pengalaman mengajar yang cukup banyak. Pengalaman mengajar tersebut dapat membuat guru memiliki kiat tertentu ketika dihadapkan oleh murid yang beraneka ragam di kelas. Sejalan dengan penelitian oleh Ramadhanti (2013) yakni terdapat hubungan positif dan signifikan antara pengalaman mengajar terhadap kinerja guru. Kinerja guru yang baik menunjukkan guru telah terlibat aktif dan berfungsi penuh di sekolah. Kemudian mayoritas responden memiliki pendidikan terakhir S1 (82,7\%). Tingginya pendidikan terakhir pada guru dapat membentuk karakter untuk pengembangan diri dan membuka wawasan untuk memperluas pengetahuan (LP3i, n.d.). Hal tersebut sangat memungkinkan guru memiliki mindset yang lebih terbuka. Kemudian, banyak responden penelitian ini mengajar di kelas 6 yang mana masuk ke dalam kategori kelas atas. Mengajar kelas atas dianggap tidak sesulit mengajar kelas bawah. Karena murid kelas atas telah memiliki konsep yang sebelumnya telah dimiliki dan didapatkan pada saat murid berada di kelas bawah. Hal ini sesuai dengan anggapan mengajar di kelas rendah memiliki tantangan yang tidak kalah besar dibandingkan mengajar di kelas atas (Kompasiana, 2015). Hasil penelitian yang telah disebutkan di atas merupakan faktor-faktor yang dapat memengaruhi tingginya tingkat teacher well-being serta tingginya tingkat kebersyukuran dalam penelitian ini.

Pada perhitungan total skor variabel kebersyukuran, diketahui bahwa guru yang mengajar di sekolah dasar inklusi memiliki skor tertinggi pada aspek intensity dan skor terendah pada aspek span. Aspek intensity mencakup perasaan intens akibat emosi positif dari rasa syukur yang dirasakan oleh individu (McCullough, Emmons, \& Tsang, 2002). Kemudian aspek span mencakup peristiwa-peristiwa dalam hidup yang membuat seseorang merasa bersyukur. Peristiwa pandemi COVID-19 yang terjadi hingga saat ini memberikan dampak yang begitu besar. Berdasarkan pengalaman 2 tahun belakangan ini, sekolah merupakan salah satu bidang yang terdampak oleh covid-19. Banyak perubahan sistem pendidikan yang menyesuaikan kondisi ini. Pembelajaran daring dipilih sebagai alternatif pembelajaran jarak jauh untuk mengurangi potensi penyebaran virus (AlJufri, Anshari \& Wahyuni, 2021). Hal tersebut dapat menyebabkan aspek span paling rendah.

Hal-hal yang dapat dilakukan oleh guru untuk memiliki atau meningkatkan aspek kebersyukuran dalam dirinya ialah dengan membuat jurnal syukur, mengirimkan ucapan terima kasih, melihat kondisi sekeliling, mengganti kata-kata negatif dengan katakata positif, membantu orang lain kemudian mencatat hal baik yang terjadi, serta melakukan meditasi (Nada, 2020).

Selanjutnya, peneliti juga melakukan analisis tambahan berupa uji perbedaan variabel berdasarkan jenis kelamin dan lama mengajar. Hasil penelitian menunjukkan guru laki-laki memiliki tingkat teacher well-being yang lebih tinggi dibandingkan dengan guru perempuan. Hal tersebut tidak sejalan dengan hasil penelitian oleh Winesa \& Saleh (2020) yang menunjukkan bahwa tingkat teacher well-being pada guru laki-laki lebih rendah dibandingkan dengan guru perempuan. Namun, hasil tersebut juga menunjukkan bahwa tidak terdapat perbedaan yang signifikan pada teacher well-being antara responden laki-laki 
dan perempuan. Hal ini sejalan dengan penelitian oleh Collie (2014) yang menunjukkan tidak adanya pengaruh yang signifikan jenis kelamin terhadap teacher well-being.

Berdasarkan perbedaan jenis kelamin pada variabel kebersyukuran diketahui bahwa guru perempuan memiliki tingkat kebersyukuran yang lebih tinggi dibandingkan dengan guru laki-laki. Hal tersebut sejalan dengan temuan Watkins Emmons, Greaves, \& Bell (2018), bahwa kebersyukuran pada perempuan lebih tinggi jika dibandingkan dengan laki-laki. Hal ini dikarenakan perempuan lebih mudah dalam mengekspresikan rasa syukur dibandingkan dengan laki-laki. Sementara Kashdan, Mishra, Breen, \& Froh (2009) menyatakan bahwa hal ini dapat disebabkan karena adanya penilaian yang berbeda antara pria dan wanita dalam merasakan emosi kebersyukuran. Pria justru menganggap bahwa rasa syukur dapat merefleksikan kelemahan pribadi mereka, sedangkan wanita menilai rasa syukur dapat membangun dan meningkatkan relasi yang kuat dengan individu lain. Hasil penelitian menunjukkan terdapat perbedaan yang signifikan pada kebersyukuran antara responden laki-laki dan perempuan.

Berdasarkan perbedaan lama mengajar pada variabel teacher well-being diketahui tidak terdapat perbedaan yang signifikan pada teacher well- being terhadap lama waktu mengajar responden. Hal ini sesuai dengan penelitian Collie (2014) yang menunjukkan bahwa tidak ada pengaruh yang signifikan antara lama mengajar dengan teacher well-being. Selanjutnya, hasil perbedaan berdasarkan lama mengajar pada variabel kebersyukuran diketahui bahwa tidak terdapat perbedaan yang signifikan pada kebersyukuran terhadap lama waktu mengajar responden. Hal ini tidak sejalan dengan penelitian Ayudahlya \& Kusumaningrum (2019) yang menemukan bahwa masa bekerja dapat memengaruhi tingkat kesejahteraan seseorang.

\section{PENUTUP}

\section{Kesimpulan}

Berdasarkan hasil analisis korelasi dan uji hipotesis, terdapat hubungan signifikan ke arah positif antara kebersyukuran dengan teacher well-being pada guru yang mengajar di sekolah dasar inklusi. Hubungan positif antara kebersyukuran dengan teacher well-being diartikan sebagai semakin tinggi kebersyukuran maka akan semakin tinggi pula teacher well-being yang dirasakan oleh guru yang mengajar di sekolah dasar inklusi, begitu pula sebaliknya.

\section{Saran}

Bagi sekolah. Penelitian ini diharapkan dapat memberikan masukan bagi pihak sekolah agar dapat memerhatikan teacher well-being pada guru. Teacher well-being akan sangat berdampak pada kinerja guru. Tingkat teacher well-being yang tinggi akan membuat guru berfungsi secara penuh. Sekolah harus memperhatikan faktor utama yang dapat memengaruhi tingkat teacher well-being pada guru yakni dukungan sosial, forgiveness, kepribadian, selfesteem, kebersyukuran, dan spiritualitas.

Bagi guru. Guru diharapkan memiliki teacher well-being yang baik. Hal tersebut dapat dilakukan dengan cara mempertajam kompetensi yang harus dimiliki oleh pendidik seperti mampu mengolah proses pembelajaran dengan peserta didik, memiliki kepribadian yang positif, memiliki keterampilan dalam menyelesaikan tugas-tugas keguruan, serta keterampilan berkomunikasi, bersikap dan berinteraksi baik dengan peserta didik, sesama guru, orang tua siswa, dan masyarakat secara luas. Kepribadian positif yang dimaksud yakni supel, sabar, disiplin, jujur, rendah hati, berwibawa, santun, empati, ikhlas, berakhlak mulia, dan lain sebagainya.

Penelitian selanjutnya. Diharapkan setelah penelitian ini dapat dilakukan penelitian lebih lanjut mengenai pengaruh antara variabel kebersyukuran dan variabel teacher well-being. Penelitian selanjutnya dapat juga meneliti variabel lain terkait teacher wellbeing yang belum pernah diteliti sebelumnya, sehingga, dapat memperkaya teori yang baru. Kemudian memperbanyak jumlah responden yang diteliti serta memperhatikan kemerataan persebaran data. Selain itu, jika penelitian selanjutnya ingin mengambil subjek penelitian yang sama, diharapkan dapat meneliti tingkat teacher well-being pada guru yang mengajar di sekolah dasar inklusi selama pembelajaran daring di masa pandemi Covid-19.

\section{DAFTAR PUSTAKA}

Ahmad, O. (2020). Menguji PP Nomor 13 Tahun 2020 dengan Realita. Solider. https:/ / www.solider. id/baca/5999-menguji-pp-nomor-13-2020-

$\begin{array}{lllllll}r & e & a & 1 & i & t & a\end{array}$

Al-Jufri, F. M., Anshori, I., \& Fahyuni, E. F. (2021). Menjadi Guru yang Well-Being di Masa Pandemi COVID-19 (UMSIDA Press (ed.)).

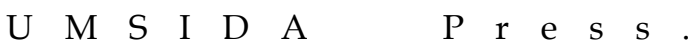
Ayudahlya, R., \& Kusumaningrum, F. A. (2019). Keber- 
syukuran dan kesejahteraan subjektif pada guru sekolah luar biasa. Psikologika: Jurnal Pemikiran Dan Penelitian Psikologi, 24(1), 13-26. https://doi.org/10.20885/psikologi. $\begin{array}{llllllllllllllll}\mathrm{v} & \mathrm{o} & 1 & 2 & 4 & \text {. } & \mathrm{i} & \mathrm{s} & \mathrm{s} & 1 & & \text { a } & \mathrm{a} & \mathrm{t} & 2\end{array}$

Collie, R. J. (2014). Understanding Teacher Well-Being and Motivation: Measurement, Theory, and Change Over Time. Paper Knowledge. Toward a Media History of Documents, Februa

$r$ $\mathrm{y}$

Collie, R. J., Shapka, J. D., Perry, N. E., \& Martin, A. J. (2015). Teacher Well-Being: Exploring Its Components and a Practice-Oriented Scale. Journal of Psychoeducational Assessment, 33(8), 744-756. https://doi.org/10.1177/0734 $\begin{array}{llllllllllll}2 & 8 & 2 & 9 & 1 & 5 & 5 & 8 & 7 & 9 & 9 & 0\end{array}$

Dewi, L., \& Nasywa, N. (2019). Faktor-faktor yang Memengaruhi Subjective Well-being. Jurnal Psikologi Terapan Dan Pendidikan, 1(1), 54. https:// doi.org/10.26555/jptp.v1i1.15129

Diener, E., Suh, E., \& Oishi, S. (1997). Recent findings on subjective well-being. Indian journal of clinical psychology, 24, 25-41.

Emmons, R. A., \& McCullough, M. E. (2003). Counting blessings versus burdens: An experimental investigation of gratitude and subjective wellbeing in daily life. Journal of Personality and Social Psychology, 84(2), 377-389.

Fatimatuzzahra, N. A. (2020). Gambaran Teachers' Well-Being pada Guru. Skripsi: Universitas $\mathrm{N}$ e $\mathrm{g}$ e $\mathrm{r}$ i $\mathrm{J}$ a $k$ a $r \mathrm{t}$ a

Hasemeyer, M. D. (2013). The Relationship Between Gratitude and Psychological, Social, and Academic Functioning in Middle Adolescence. University of South Florida., January, https:// scholarcommons.usf.edu/cgi/viewcontent. C $\quad \mathrm{g} \quad \mathrm{i}$

Kashdan, T. B., Mishra, A., Breen, W. E., \& Froh, J. J. (2009). Gender differences in gratitude: Examining appraisals, narratives, the willingness to express emotions, and changes in psychological needs. Journal of Personality, 77(3), 691-730. https://doi.org/10.1111/j.1467-64 $\begin{array}{lllllllllllllll} & 4 & . & 2 & 0 & 0 & 9 & \text {. } & 0 & 0 & 5 & 6 & 2 & \text {. } & \end{array}$

Kompasiana. (2015). Mengajar Kelas Rendah (1-3) itu Mudah. Benarkah? Kompasiana. https:/ / www.kompasiana.com/semanagatjuang/ 550aecd8a33311b10a2e3af7/mengajar-kelasrendah-1-3-itu-mudah-benarkah Lp3i. (n.d.). Memahami Tujuan Kuliah dan Manfaatnya. https://www.lp3i.ac.id/memahami-tujuan$\mathrm{k} \mathrm{u} l$ i a h-d a n-m a n f a t n y a /
McCullough, M. E., Emmons, R. A., \& Tsang, J. A. (2002). The grateful disposition: A conceptual and empirical topography. Journal of Personality and Social Psychology, 82(1), 112-127. https://doi.org/10.1037/0022-3514.82.1.112

Nada, E. (2020). Membuat Jurnal Syukur dan 5 Cara Melatih Sikap Bersyukur. CewekBanget.ID. https://cewekbanget.grid.id/read/062279 723/membuat-jurnal-syukur-dan-5-caramelatih-sikap-bersyukur-wajib-coba?page=all Nofriza, F. (2020). Mempersiapkan Diri Memasuki Dewasa Awal. UHAMKA, Fakultas Keguruan Dan Ilmu Pendidikan. https:/ / fkip.uhamka. ac.id/galery-kegiatan/wacana/mempersiapkan-diri-memasuki-dewasaawal/

Putri, D. A., Sukarti, S., \& Rachmawati, M. A. (2016). Pelatih Kebersyukuran untuk Meningkatkan Kualitas Hidup Guru Sekolah Inklusi. JIP (Jurnal Intervensi Psikologi), 8(1), 21-40.

Ramadhanti, N. (2013). Pengaruh Pengalaman Mengajar dan Banyaknya Pelatihan yang Pernah Diikuti terhadap Kinerja Guru SD Se-Sekbin 1 Kecamatan Ketanggungan Kabupaten Brebes. Joyful Learning Journal, 2(2). https:/ / doi. or g / $10.15294 / \mathrm{jlj}$.v2 i 2.1841

Stark, R., Gordon-Burns, D., Purdue, K., Rarere-Briggs, B., \& Turnock, K. (2011). Other parents' perceptions of disability and inclusion in early childhood education: Implications for the teachers' role in creating inclusive communities. He Kupu: The Word, 2(4), 4-18. Wahyudi, W., \& Kristiawati, R. (2016). Gambaran Sekolah Inklusif di Indonesia: Tinjauan Sekolah Menengah Pertama. Gambaran Sekolah Inklusif Di Indonesia, xi-95. http:/ / publikasi. data.kemdikbud.go.id/uploadDir/isi_14D 0F106-F4EE-486B-A74F-84A191B4AD25_.pdf

Watkins, P. C., Emmons, R. A., Greaves, M. R., \& Bell, J. (2018). Joy is a distinct positive emotion: Assessment of joy and relationship to gratitude and well-being. Journal of Positive Psychology, 13(5), 522-539. https://doi.org/10. $1080 / 17439760.2017 .1414298$

Winesa, S. A., \& Saleh, A. Y. (2020). Resiliensi sebagai prediktor teacher well-being (resilience as a predictor of teacher well-being). Mind Set, 11 ( 2 ), $116-128$. 